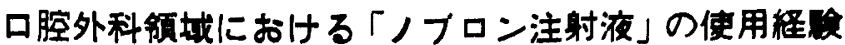

竹屋 隆 典*

\section{［I] 緒}

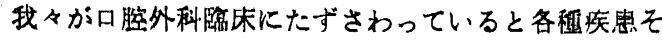

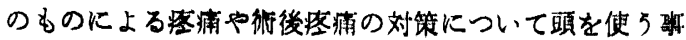
が多い，しかもこれらの疼痛を鎮静綬解せしめる碎は治 祭の刘果を発掦させ，その成跤を向上させるためにも必 要な姑であ、渄近クロルプロマジンがいわゆる人工冬

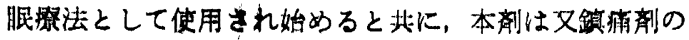
奻果を增強させる事か知られ，この方面に対する烸床的 応用籄围が拡大されて来た。「ノブロン注射液」はグレ ラン製薬によって製品化されたクロルプロマジン，グレ ラン，塩酸ジフェンヒドラミンの合郕であるが我が教室 において最近同社より提供された本剤を試用し臨床好果 を実験し得たので小数例ではあるがここにその試用効果 を報告する次第である。

\section{[II] 㩆 朱 成}

\section{（1）使用至及ひ使用法}

「ノプロン注射夜」はクロルプロマジンの自律神経遮 断作用並びに中枢作用に基く鎮痛, 催眠, 鎮静作用とグ レランの䈯痛, 鎮浄作用とが相乗的に強化発現すると共 に塩酸ジフェンヒドラミンにより催眠作用が強化される 疼痖治療片であり,クロルプロマジン, グレランの含有 量により「ノブロン注射液 $\mathrm{A} 」 お$ よび「B」の 2 種類が 慗品化されている.

即ち「A」任1管 $2 \mathrm{cc}$ 中クロルプロマジン $12.5 \mathrm{mg}$ ，
グレラン $200.0 \mathrm{mg}$ ，醏酸ジフェンヒドラミン $20.0 \mathrm{mg}$ ， を「B」は1管 $2 \mathrm{cc}$ 中クロルプロマジン $25.0 \mathrm{mg}$, タ レラン $300.0 \mathrm{mg}$, 塭酸ジフェレドラミン $20.0 \mathrm{mg}$. を含有している，使用の対像としては，入院を要した各 種口腔外科疾患，ことに手術施行後の疼綝およびこれに ともな5睡眠障碍等総数 35 例で，年令は 8 才から60才

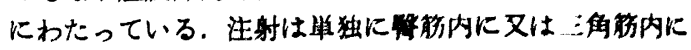

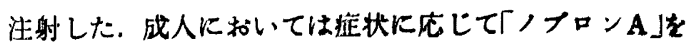
1 回 $2 \mathrm{cc} \sim 4 \mathrm{cc}$ ，又は「ノフロンB」を2cc 筋注し，年

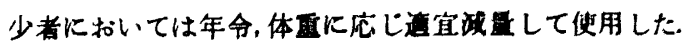

\section{（2）侙用成綪について}

試用の対象としては一定期间内に造週した各的疾艒の 入院㭧者中疼痛や不眠および苦低を訴えるるのを主体と し，別表の如く現在迄 35 例付対してた用した，その内 分汁は最初から疼痛を訴えて入院した各括资拉性疾急意 者に対する鎮静の目的扰よびその術後に応用したいの16 例，骨折，上影洞炎根治手術或は整形手街等主として麻

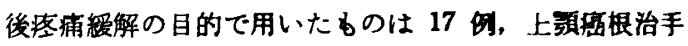
術後の再発による做南を訴えるるの 2 例等である. その 応用効果は別表の如くであって，表中の圽果は次の基隼 に基いて判定した。 (1) 著奻（卅）, 鎮綃催眠作用が著明 に認められたもの. (2) 有效 (H), 金槙峍眠作用が相当 認められ疼痛に酎之る事が出来た6の. (3) 稍有协 $(+)$, 鎮痛催眠作用は認めるか，尚不充分であったるの. (1)無 効 (一)、鎮有催眠作用がはとんど認められなかったも の.

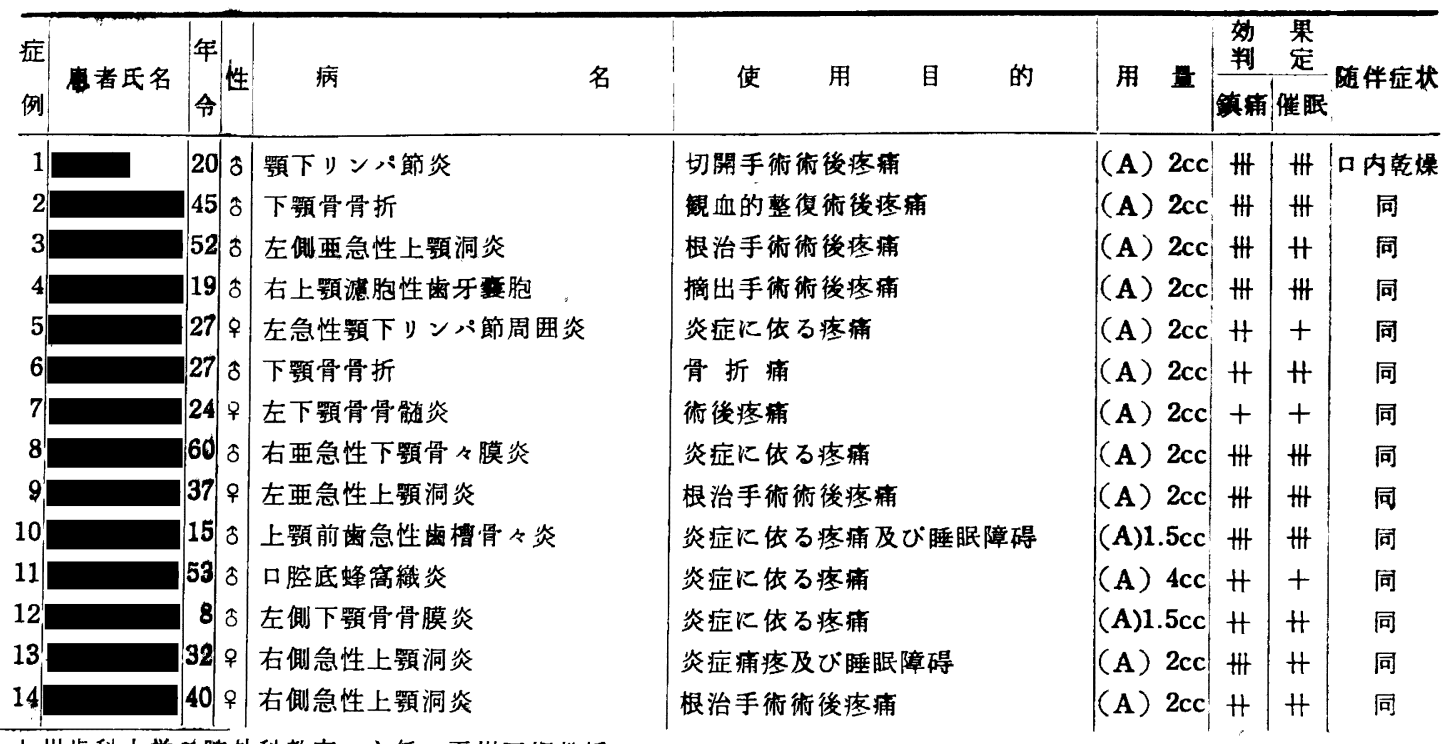




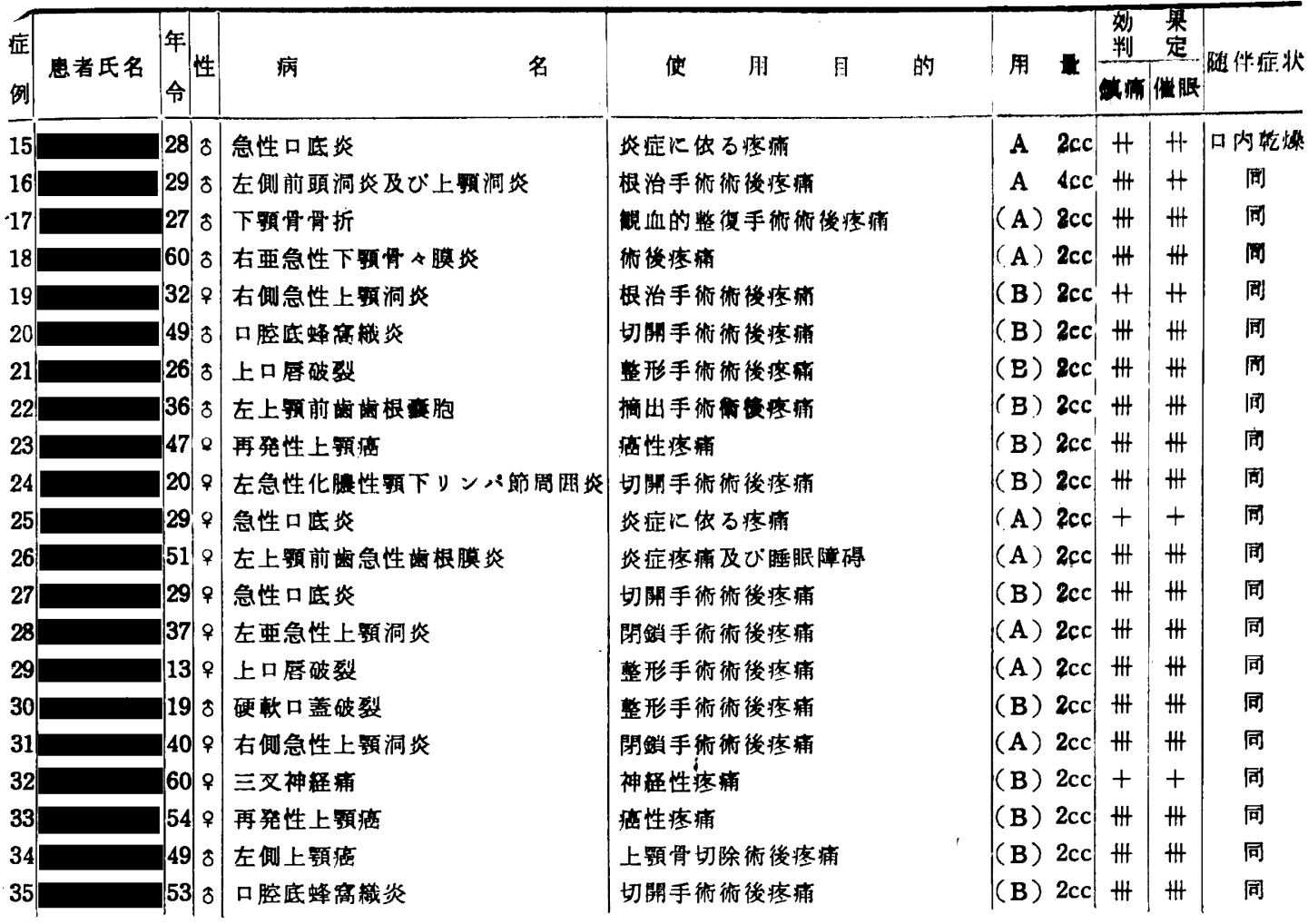

〔症例 I〕患者—20才 今（表第1例）

主訴頋下部より左右㖽下ならびに上頸部におよぶ 発赤腫脹疼痛および嬹下庯. 患者は来院数日前より䫑下 リンパ節の腫脹疼庯を来し某齿科医院にてペニシリン注 射 3 回を受けたが治空傾向が見られず, 昭和 31 年 12 月 口日当院へ入院. 穎下部に䇣張と波動をふれるのでたた ちに局所麻酔の下に切開手術を行 5. 手術後 30 分位に して次第に增強する局所庝痛を訴えるので「ノフロンA」 $2 \mathrm{cc}$ を筋注す (19時). 2 〜 3 分にて口渴を自覚すると 同時に疼痛は消失し睡眠を催す，翌朝 8 時頃迄効果継続 し覚醒す、それ以後の疼凊は全く訴えず好結果を得た 1 例である。

\section{〔症例 II] 患者—19才 $。$ （表第 30 例）}

主訴：口蓋裂扣よび発語障碍. 昭和 32 年 2 月以日 硬軟口蓋裂の整形手術を行った。術後䄪 1 時間にして疼 痡を訴えたので「ノブロンB」2ccを腎能に注射す (18 時). 約 3 分立にして疼痡は消退すると共に睡眠に入り 翌朝 9 時頃附添の呼声により覚醒し疼痛は全然感じなか ったという．就眠前および覚醒時強度の口渴を訴えてい た. 本例は注射後䄪 15 特間効果が継続し, 術後の疼痛 は全く感じなかった著効例である。

〔症例 III 患者—47才早（表第23 例） 主訴：上顎癌再発による疼痡および睡眠障碍.

本例は右側上顎癌根治手術後再発により数 10 日間に
わたる持綕性の頙痛および局所の激痛と不眠に悩んだ症 例であり，「ノブロンB」2 cc 笳肉注射を行った所, 生 射後 1 分にして口内乾煤を催し 3 分にして完全に疼痛消 失し 10 分後には睡眠してしまった．以上のよ $5 に$ 効果 は多くの例においては筋注後，3～15 分位に発現するよ うである. 即ちこの位の時間において疼痡の消退と共に 催眠発現へと移行して行く．著奻群 25 例においては睡 眠し疼痛を訴えない時間が 8〜15 時間で，覚醒しても疼 痛は全く消失している症例が多かった，有効群 7 例にお いては睡眠時間は5〜8時間で，覚醒しても疼痡には耐 えられる状態である。稍有効群 3 例では催眠作用は認め られるが浅くて疼痛緩解も不充分であった.

\section{（3）副作用むよび随伴症状}

クロルプロマジンの副作用については，中枢神経系， 心茂血管系, 消化器系, 呼吸器系, 泌尿器系等に現れる がこれは大量を長期にわたり使用する際に問題となる. 本剂 1 筒の含有量程度では余り問題にならない.しかし ながらクロルプロマシンに対する感受性の個人差はかな り著しいるのがあり, 時には $25 \mathrm{mg}$ 程度の使用によっ ても血圧低下，悪心，㗐吐等を起す事もあるので北原も その報告を述べているよ5に本剤も初回投与時には充分 注意を期する事が心要である．私は本剤投与後血圧，呼 吸数, 悪心, 嘔吐, 黄疸の有無等に充分な注意を払って 観察したが 1 例もこれらの副作用は認めなかった。唯 
随伴的な症状として沙射後の川谒感は相当時間全症例に おいて認められた，尚本詴泣:射後は速かな做眠作用が现 れるので通院费者に使用する新は道当でないと考える。

\section{[III] 給括及び考披}

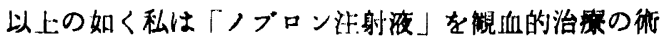
後疼痛に対する 22 例と，非覞血的治滕中の㤏痛および 睡眠猝碍の喼者に対する 13 例の合䑒 35 例に本郕を用

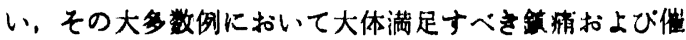
眠作用を琶める事が出来た，その协果においては备くの

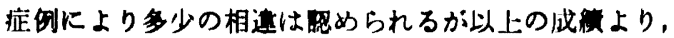

「ノブロン泩射夜」は口腔外科湎域における疼痛をとる な5各程疾腎拉よび㭪後の疼痛に対して者しい，しかも

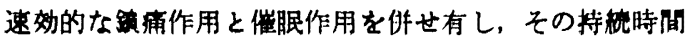

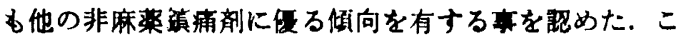
れらの優秀なる奻果はクロルプロマジンおよびダレラン の相乗作用とさらに抗ヒスタミン郕の塩酸ジフェンヒド ラミンの作用がこれに加わる事によるものと思われる。 術後疼痛䑨烈のため，睡眠不可能な症例においても注射 後 3 分前後で疼痛消失し，催眠した例もかなりある．镇 痡持繌時間は大体において 10 時間前後で表中有効群の ほとんどの症例は觉醒後疼痛を訴えなかった，使用した 時間は主に夜間においてであり昼間に使用した症例 5 ，

$7 ， 14 ， 15 ， に お い て は$ 別表の如く著効は認められなか った．非手術例の疼痡に対しても大多数例に括いて有奻 であった．本鼡は従来使用して来た管浦郕の投与時に比 べその奻果は，適応の澱定を誤らなければ顕著なものと いえる. 時にグレランのみの単独使用に比較し奻果は大 である.

\section{[IV] 結}

Uin

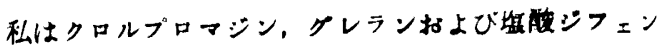

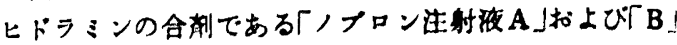

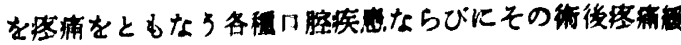

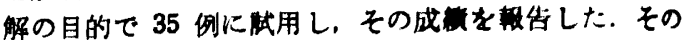
絬果によれば注射後速かな楼有の消失と业に睡眠に移行

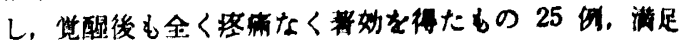

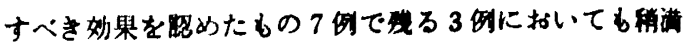

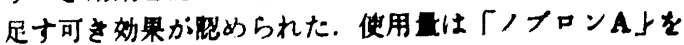

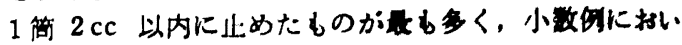
ては「A」を2简又は「B」1简を使用し前記の成賞を

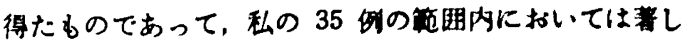

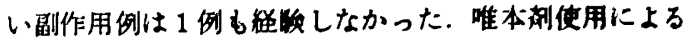

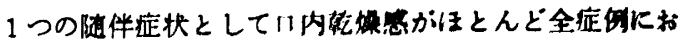
いて覠められた。

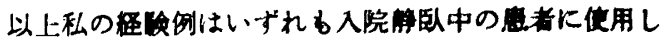

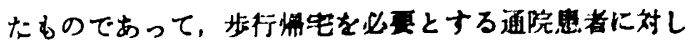

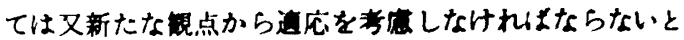

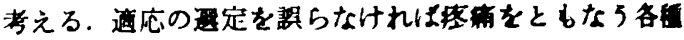
口腔疾患ならびに口腔外科的手街後の反庆性烃需に対す る有効なる莱剂と做す事が出来る。

筆を诚くにあたり御校閲を賜った平川正和教授に感啸 すると共に医局員諸氏の御協力に謝意を表します。

本論文の要旨は昭和 32 年3月 23 日九州龁科学会明 会において赫告した。

\section{[V] 女 到}

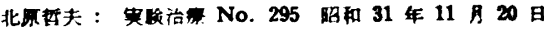

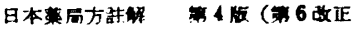

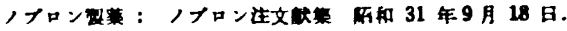

